\title{
SEASONAL CHANGES IN SOIL RESPIRATION OF DEGRADED AND NON-DEGRADED SITES IN OAK AND PINE FORESTS OF CENTRAL HIMALAYA
}

\author{
B.S. Jina ${ }^{1}$, C.P.S. Bohra ${ }^{2 *}$, Y.S. Rawat ${ }^{1}$ and M.D. Bhatt ${ }^{3}$ \\ ${ }^{1}$ Department of Botany, Kumaun University, Nainital India-263-002 \\ ${ }^{2}$ Department of Forestry, Kumaun University, Nainital India-263-002 \\ ${ }^{3}$ Department of Botany, Siddhanath Science Campus Mahendranagar, Nepal
}

\begin{abstract}
Present investigation deals with the seasonal changes in soil respiration of degraded and non-degraded oak and pine forests in Van Panchayat of Kumaun Himalaya. Soil temperature and soil moisture enhances soil respiration by increasing microbial activity and decomposition of organic matter. The rate of soil respiration was higher in non-degraded site of oak forest in Dhaili VP (63.9 \pm 1.6 to 363.6 $\left.\pm 5.3 \mathrm{mg} \mathrm{CO}_{2} \mathrm{~m}^{-2} \mathrm{~h}^{-1}\right)$, non-degraded site of pine forest $\left(39.1 \pm 0.9\right.$ to $\left.195.41 .6 \mathrm{mg} \mathrm{CO}_{2} \mathrm{~m}^{-2} \mathrm{~h}^{-1}\right)$ in Guna VP, and lower in degraded pine forest in Toli VP (21.3 \pm 0.5 to $\left.126.8 \pm 0.8 \mathrm{mg} \mathrm{CO}_{2} \mathrm{~m}^{-2} \mathrm{~h}^{-1}\right)$, degraded oak forest of Guna VP was (26.9 \pm 0.8 to $167.3 \pm 1.2 \mathrm{mg} \mathrm{CO}_{2} \mathrm{~m}^{-2} \mathrm{~h}^{-1}$ ). Within non-degraded and degraded sites of both oak and pine forests soil respiration was positively correlated with soil temperature and soil moisture.
\end{abstract}

Key words: Soil respiration; Degraded; Non-dedgraded; Van panchayat.

\section{INTRODUCTION}

Soil respiration is the primary path by which $\mathrm{CO}_{2}$ fixed by land plants returns to the atmosphere. Soil respiration represents the sum total of all metabolic process in which $\mathrm{CO}_{2}$ is produced. It includes the respiration of microorganism, soil animals and roots. In every ecosystem most of the organic matter added to the soil is in the form of litter, dead biomass, or root is processed through microbial and micro faunal activity, resulting in the production of $\mathrm{CO}_{2}$ and the release of nutrients. Thus the rate of $\mathrm{CO}_{2}$ released from soil is a major index of total metabolic activity (Joshi et al. 1991; Joshi and Rawat 2005).

The main objectives of the present investigation was to examine the differences in studying soil respiration rate between degraded and non-degraded sites of oak and pine forest and for determining the dependence of soil respiration on some selected edaphic condition and seasonal variations.

\section{MATERIALS AND METHODS}

The study sites are located in the Van Panchayats (VPs) of Dhaili, Toli, and Guna located in Lamgara block of Almora district in Uttaranchal. The Van Panchayats of Dhaili, Toli, and Guna are situated between $79^{\circ} 41.4^{\prime}-79^{\circ} 43.2^{\prime}$ E longitudes and $29^{\circ} 32.9^{\prime}-29^{\circ} 34.3^{\prime}$ latitudes with the elevation of $1800-2000 \mathrm{~m}$. Originally referred to as the crystalline zone of Almora by Heim and Gansser (1939) and commonly known “Almora crystallines”, this vast over thrust succession of a variety of schists, micaceous quartizimeta morphism and with concordantly emplaced plutonic bodies of granodiorites and granites is renamed Almora group (Valdiya, 1980) after the township of Almora.
The selection criterion for degraded and non-degraded sites were presence and absence of regeneration, crown cover, number of lopped branches, fodder extraction and grazing. Climate of the area was referred to as monsoon warm temperate. The mean annual rainfall was $921.9 \mathrm{~mm}$ and mean monthly maximum temperature varied from 16.7 to $31.5^{\circ} \mathrm{C}$ and minimum from 6.5 to $19.2^{\circ} \mathrm{C}$.

In the three main seasons winter was cold and dry (December to February), summer was warm and dry (April to mid June) and rainy was warm and humid (mid June to mid September). Severe frost is usual throughout the winters with frequent snowfall. Snow may last in shaded micro sites for a number of weeks.

Three soil samples from different locations in triplicate were collected randomly for each microsite from $0-30 \mathrm{~cm}$ soil depth and measured (Mishra, 1968).

$\mathrm{CO}_{2}$ evolution was measured by alkali absorption method (Gupta and Singh, 1977) using aluminum cylinder (13 x $23 \mathrm{~cm}$ ) inserted $10 \mathrm{~cm}$ into ground and 1:20 ratio of alkali absorption to soil area (Kirita, 1971). Three replicates of experimental cylinders were setup. Before each cylinder fixed, the green vegetation were totally removed falling inside the cylinder.

A $50 \mathrm{ml}$ beaker containing $20 \mathrm{ml} 0.5 \mathrm{NaOH}$ (Gupta and Singh, 1977) was hung on a thin wire in each cylinder. The alkali was titrated against $1 \mathrm{~N} \mathrm{HCl}$ after 24 hour absorption period to avoid diurnal variation (Harris and Van Bavel, 1957). The cylinders were placed randomly and on each sampling date soil temperature was measured with a soil thermometer. Evolved $\mathrm{CO}_{2}$ during experiment was calculated using given formula (Misra, 1968): 
Table 1: Soil respiration, temperature and moisture in the non-degraded and degraded sites of oak and pine forests.

\begin{tabular}{|c|c|c|c|}
\hline Site name & Summer & Rainy & Winter \\
\hline \multicolumn{4}{|c|}{ Soil respiration $\left(\mathrm{mg} \mathrm{CO}_{2} \mathrm{~m}^{-2} \mathrm{ha}^{-1}\right)$} \\
\hline \multicolumn{4}{|l|}{ Non-degraded oak sites } \\
\hline Dhaili Van Panchayat & $169.3 \pm 3.7$ & $363.6 \pm 5.3$ & $63.9 \pm 1.6$ \\
\hline Guna Van Panchayat & $172.2 \pm 4.1$ & $350.1 \pm 4.9$ & $62.5 \pm 1.4$ \\
\hline \multicolumn{4}{|c|}{ Non-degraded pine sites } \\
\hline Guna Van Panchayat & $106.2 \pm 1.7$ & $195.4 \pm 1.6$ & $39.1 \pm 0.9$ \\
\hline Toil Van Panchayat & $100.5 \pm 1.8$ & $189.5 \pm 2.4$ & $35.4 \pm 1.0$ \\
\hline \multicolumn{4}{|l|}{ Degraded oak sites } \\
\hline Guna Van Panchayat & $78.2 \pm 0.9$ & $167.3 \pm 1.2$ & $26.9 \pm 0.8$ \\
\hline Dhaili Van Panchayat & $81.6 \pm 1.2$ & $171.1 \pm 1.1$ & $29.5 \pm 0.6$ \\
\hline \multicolumn{4}{|l|}{ Degraded pine sites } \\
\hline Guna Van Panchayat & $62.5 \pm 1.7$ & $118.5 \pm 0.7$ & $24.5 \pm 0.6$ \\
\hline Toil Van Panchayat & $70.8 \pm 1.3$ & $126.8 \pm 0.8$ & $21.3 \pm 0.5$ \\
\hline \multicolumn{4}{|c|}{ Soil temperature $\left({ }^{\circ} \mathrm{C}\right)$} \\
\hline \multicolumn{4}{|l|}{ Non-degraded oak sites } \\
\hline Dhaili Van Panchayat & $19.4 \pm 0.23$ & $17 \pm 0.40$ & $8.0 \pm 0.02$ \\
\hline Guna Van Panchayat & $19.6 \pm 0.40$ & $16.5 \pm 0.52$ & $7.9 \pm 0.03$ \\
\hline \multicolumn{4}{|c|}{ Non-degraded pine sites } \\
\hline Guna Van Panchayat & $22.7 \pm 0.46$ & $20.1 \pm 0.20$ & $10.9 \pm 0.02$ \\
\hline Toil Van Panchayat & $23.1 \pm 0.23$ & $20.1 \pm 0.23$ & $11 \pm 0.01$ \\
\hline \multicolumn{4}{|l|}{ Degraded oak sites } \\
\hline Guna Van Panchayat & $21.8 \pm 0.32$ & $19.7 \pm 0.29$ & $8.2 \pm 0.23$ \\
\hline Dhaili Van Panchayat & $19.5 \pm 0.17$ & $17.5 \pm 0.20$ & $9.3 \pm 0.23$ \\
\hline \multicolumn{4}{|l|}{ Degraded pine sites } \\
\hline Guna Van Panchayat & $23.3 \pm 0.29$ & $20.4 \pm 0.17$ & $10.6 \pm 0.01$ \\
\hline Toil Van Panchayat & $21.67 \pm 0.44$ & $19.8 \pm 0.46$ & $9.7 \pm 0.29$ \\
\hline \multicolumn{4}{|c|}{ Soil moisture (\%) } \\
\hline \multicolumn{4}{|l|}{ Non-degraded oak sites } \\
\hline Dhaili Van Panchayat & $27.7 \pm 0.37$ & $50.5 \pm 1.04$ & $33.57 \pm 1.16$ \\
\hline Guna Van Panchayat & $28.63 \pm 1.13$ & $49.0 \pm 1.73$ & $38.23 \pm 1.22$ \\
\hline \multicolumn{4}{|c|}{ Non-degraded pine sites } \\
\hline Guna Van Panchayat & $25.2 \pm 0.91$ & $46.1 \pm 1.48$ & $39.1 \pm 0.80$ \\
\hline Toil Van Panchayat & $23.4 \pm 0.47$ & $43.27 \pm 1.13$ & $34.77 \pm 1.3$ \\
\hline \multicolumn{4}{|l|}{ Degraded oak sites } \\
\hline Guna Van Panchayat & $16.43 \pm 0.47$ & $36.67 \pm 1.09$ & $28.57 \pm 0.74$ \\
\hline Dhaili Van Panchayat & $17.9 \pm 0.21$ & $33.5 \pm 1.32$ & $30.7 \pm 0.88$ \\
\hline \multicolumn{4}{|l|}{ Degraded oak sites } \\
\hline Guna Van Panchayat & $22.31 \pm 0.71$ & $34.5 \pm 0.76$ & $27.23 \pm 0.39$ \\
\hline Toil Van Panchayat & $21.4 \pm 0.49$ & $32.0 \pm 0.58$ & $25.9 \pm 0.97$ \\
\hline
\end{tabular}

$$
\mathrm{mg} \mathrm{CO}=\mathrm{V} \times \mathrm{N} \times 22
$$

Where, $\mathrm{V}$ represents titration of blank minus sample titration and $\mathrm{N}$ is the normal acid value.

\section{RESULTS}

Seasonal pattern for total soil respiration $\left(\mathrm{mg} \mathrm{CO}_{2} \mathrm{~m}^{-2} \mathrm{~h}^{-1}\right)$ was identical in both non-degraded and degraded sites. Value was highest in rainy season (wet and warm) and lowest during winters (cold and moderately dry). Rainy season value was approximately twice the summer value at all sites, and three to five times higher than the winters (Table 1).

Regardless of season, rate of soil respiration was higher in

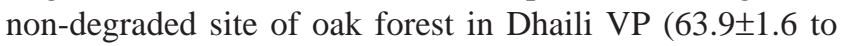
$363.6 \pm 5.3 \mathrm{mg} \mathrm{CO}_{2} \mathrm{~m}^{-2} \mathrm{~h}^{-1}$ ), non-degraded site of pine forest (39.1 \pm 0.9 to $195.41 .6 \mathrm{mg} \mathrm{CO}_{2} \mathrm{~m}^{-2} \mathrm{~h}^{-1}$ ) in Guna VP, and lower in degraded pine forest in Toli VP (21.3 \pm 0.5 to $126.8 \pm 0.8 \mathrm{mg} \mathrm{CO}_{2}$ $\left.\mathrm{m}^{-2} \mathrm{~h}^{-1}\right)$, degraded oak forest of Guna VP was (26.9 \pm 0.8 to 167.3 $\pm 1.2 \mathrm{mg} \mathrm{CO}_{2} \mathrm{~m}^{-2} \mathrm{~h}^{-1}$ ) (Table 1 ). Within non-degraded and degraded sites of both oak and pine forests soil respiration was positively correlated with soil temperature and soil moisture (Figure 1 and 2). 


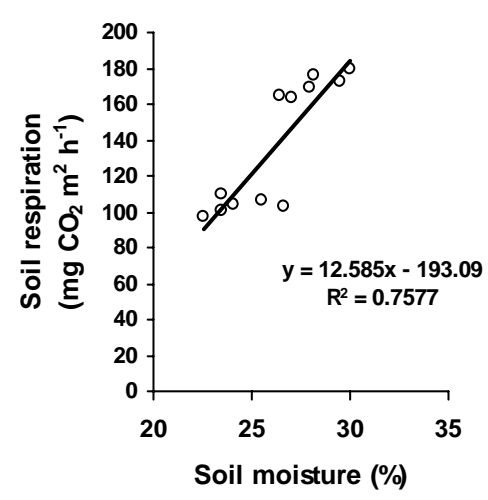

(A)

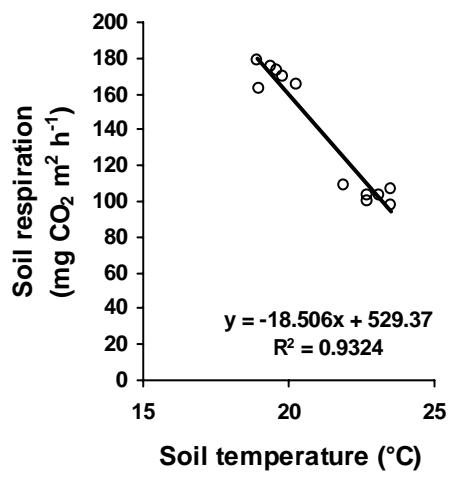

(B)

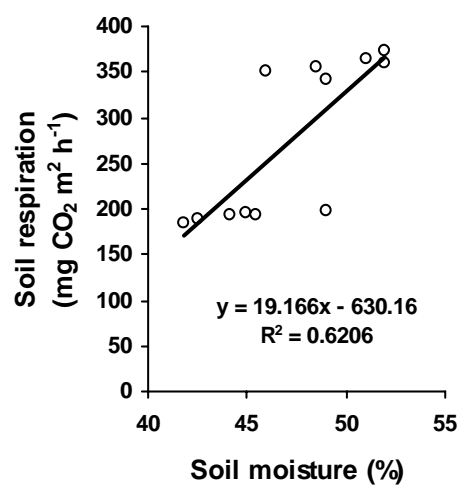

(A)

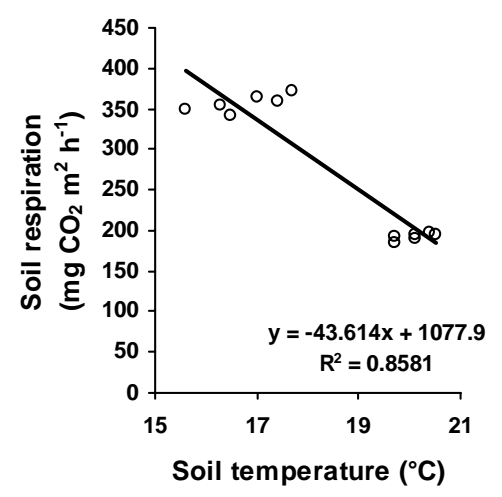

(B)

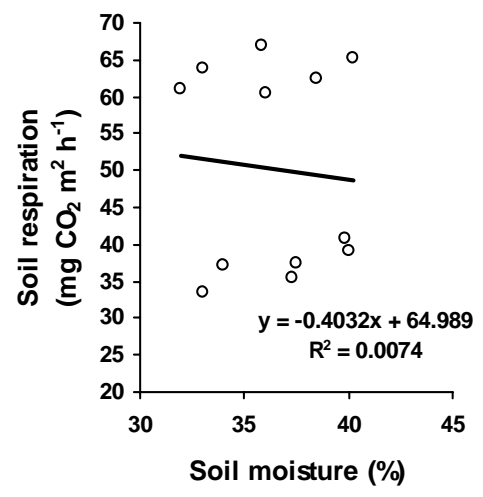

(A)

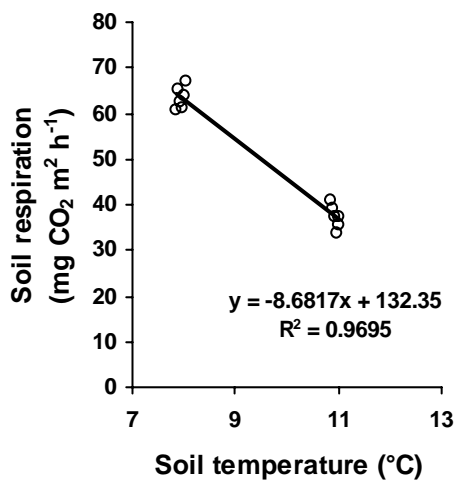

(B)

Winter - Non-degraded

Fig. 1: Relationship between total soil respiration $\left(\mathrm{mg} \mathrm{CO}_{2} \mathrm{~m}^{-2} \mathrm{~h}^{-1}\right)$ with soil moisture and temperature in non-degraded sites of oak (A) and pine (B) forests. 


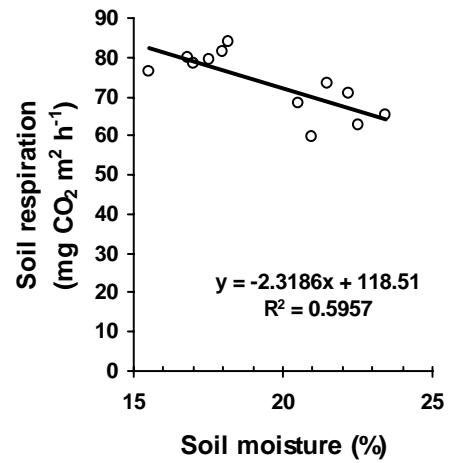

(A)

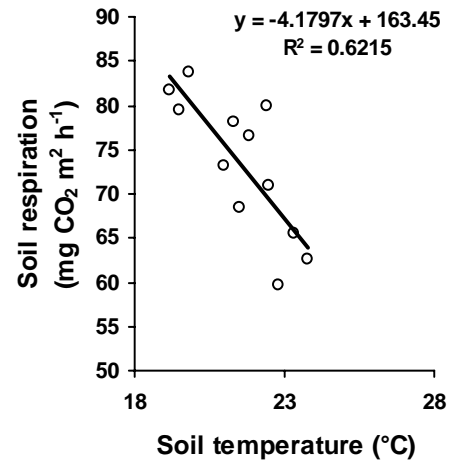

(B)

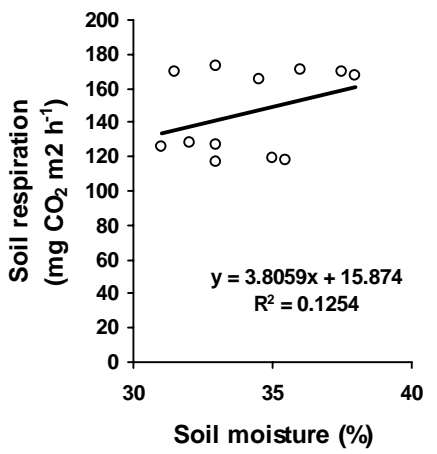

(A)

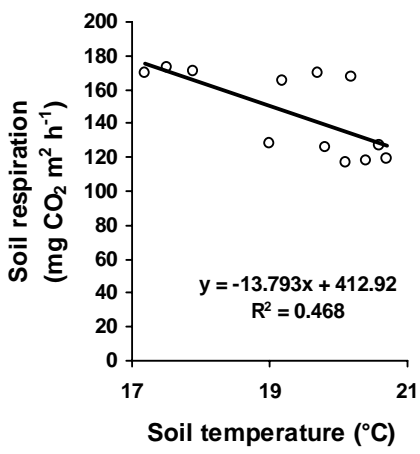

(B)

Rainy - Degraded

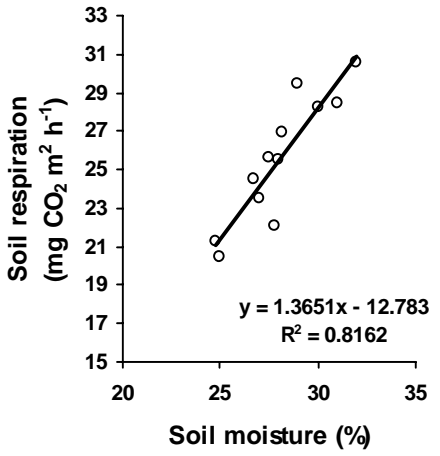

(A)

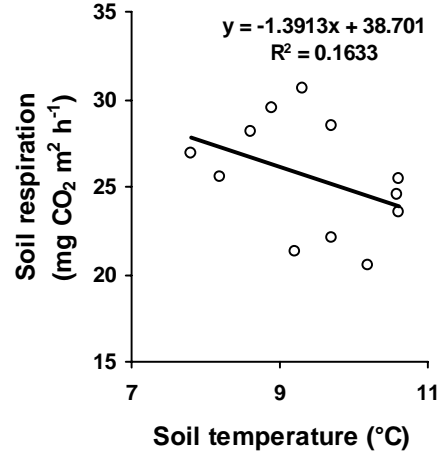

(B)

Winter - Degraded

Fig. 2: Relationship between total soil respiration ( $\mathrm{mg} \mathrm{CO}_{2} \mathrm{~m}^{-2} \mathrm{~h}^{-1}$ ) with soil moisture and temperature in degraded sites of oak (A) and pine (B) forests. 


\section{DISCUSSION}

In the present study values for total soil respiration were markedly higher in rainy season than during the others. $\mathrm{CO}_{2}$ evolution from soil-litter system is governed directly or indirectly by two major environmental factors, i.e., temperature and moisture (Singh and Gupta, 1977) both of which were high during rainy season. Available soil moisture enhances soil respiration by increasing microbial activity and decomposition of organic matter (Witkamp, 1963; Anderson, 1973; Gupta and Singh, 1977). Seasonal variations in the physical environment were known to be wider in open sites than in forested sites (Larcher, 1980). This was clearly reflected in seasonal variations of total soil respiration. The total soil respiration values ranged from 206 to $333 \mathrm{mg} \mathrm{CO}_{2} \mathrm{~m}^{-2} \mathrm{~h}^{-1}$ during rainy season for central Himalayan oak and conifer forests (Tewari et al., 1982). The soil respiration values of non-degraded and degraded sites of oak and pine forests of present study were in agreements with findings of other workers in temperate forest soils like Leith and Quellette (1962), Singh and Gupta (1977), Stubbing (1977), Weber (1985), Tewari et al. (1982), Joshi et al. (1991) and Joshi and Rawat (2005).

\section{ACKNOWLEDGMENTS}

Authors are greatly thankful to Head, Department of Botany for providing necessary facilities and encouragement throughout the course of study. Mr. Mukund Kumaiyan also deserves special mention for assisting manuscript.

\section{REFERENCES}

Anderson, J.M. 1973. The breakdown and decomposition of sweet chestnut (Castanea sativa Mill.) and beech (Fagus sylvatica L.) leaf litter in two deciduous woodland soils. I. breakdown, leaching, and decomposition. Oecologia, 12:251-274.

Gupta, S.R., and Singh, J.S. 1977. Effect of alkali concentration, volume and absorption area on the measurement of soil respiration in a tropical sward. Pedobiologia, 17:233-239.
Harris, D.G., and Van Bavel, G.H.M. 1957. Root respiration in tobacco, cotton, corn and cotton plants. Agron. J., 49: 182-184.

Heim and Gansser 1939. Central Himalaya geological observation of the swiss expedition. Mem. Soc. Helv. Sci. Nat., 73:1-245pp.

Joshi, B. and Rawat, Y.S. 2005. Seasonal changes in total soil respiration and seedling respiration in a disturbed Quercus floribunda Lindl. forest of central Himalaya. Ecol. Env. and Cons. Enviromedia, 12(1):49-55.

Joshi, M., Mer, G.S., Singh, S.P. and Rawat, Y.S. 1991. Seasonal pattern of total soil respiration in undisturbed and disturbed ecosystems of central Himalaya. Biol. Fertil. Soils, 11:267-272.

Kirita, H. 1971. Re-examination of the absorption method of measuring soil respiration under field conditions: II Effect of the size of the apparatus on $\mathrm{CO}_{2}$ absorption rates. Jpn. J. Ecol., 21:37-42.

Larcher, W. 1980. Physiological plant ecology. Springer-Verlag, Berlin, Heidelberg, New York, 303p.

Leith, H. and Quellette, R. 1962. Studies on the vegetation of the Gaspe peninsula: II. The soil respiration of some plant communities. Can J. Bot., 40:127-140.

Misra, R. 1968. Ecology workbook, Oxford and IBH publishing Co. Calcutta, 224p.

Singh, J.S. and Gupta, S.R. 1977. Plant decomposition and soil respiration in terrestrial ecosystem. Bot. Rev., 43:449-528.

Steubing, L. 1977. Soil microbial activity under beech and spruce stands. Nat. Can. (Ottawa), 104:143-150.

Tewari, C.K., Pandey, U. and Singh, J.S. 1982. Soil litter respiration rates in different micro-habitats of mixed oak-conifer forest and their control by edaphic conditions and substrate quality. Plant and Soil, 65:233-238.

Valdiya, K.S. 1980. Geology of Kumaun lesser Himalaya. Wadia institute of Himalayan Geology, Dehradun 291p.

Weber, M.G. 1985. Forest soil respiration in eastern Ontario jack pine ecosystem. Can. J. For. Res., 15:1069-1073.

Witcamp, M. 1963). Microbial population of leaf litter in relation to environmental conditions and decomposition. Ecology, 44:372-377pp. 